Georgia State University

ScholarWorks @ Georgia State University

$5-2-2018$

\title{
The Effects of Differential Pay on Teacher Recruitment and Retention
}

Carycruz Bueno

Georgia State University, cbueno1@student.gsu.edu

Tim R. Sass

Georgia State University, tsass@gsu.edu

Follow this and additional works at: https://scholarworks.gsu.edu/uwrg_workingpapers

\section{Recommended Citation}

Bueno, Carycruz and Sass, Tim R., "The Effects of Differential Pay on Teacher Recruitment and Retention" (2018). UWRG Working Papers. 121.

https://scholarworks.gsu.edu/uwrg_workingpapers/121

This Article is brought to you for free and open access by the Usery Workplace Research Group at ScholarWorks @ Georgia State University. It has been accepted for inclusion in UWRG Working Papers by an authorized administrator of ScholarWorks @ Georgia State University. For more information, please contact scholarworks@gsu.edu. 


\section{W. J. Usery Workplace Research Group Paper Series}

Working Paper 2018-5-2

May 2018

\section{The Effects of Differential Pay on Teacher Recruitment and Retention}

Carycruz Bueno

Georgia State University

Tim R. Sass

Georgia State University

\section{ANDREW YOUng SCHOOL}




\section{The Effects of Differential Pay on Teacher Recruitment and Retention*}

\author{
Carycruz Bueno \\ Department Economics \\ Andrew Young School of Policy Studies \\ Georgia State University \\ Atlanta, GA 30303 \\ Email: cbueno1@student.gsu.edu
}

\author{
Tim R. Sass \\ Department of Economics \\ Andrew Young School of Policy Studies \\ Georgia State University \\ Atlanta, GA 30303 \\ Email: tsass@gsu.edu
}

May 23, 2018

Traditionally, teacher salaries have been determined solely by experience and educational attainment. This has led to chronic shortages of teachers in particular subject areas, such as math, science and special education. We study the first long-running statewide program to differentiate teacher pay based on subject area, Georgia's bonus system for math and science teachers. Using a difference-in-differences strategy, we find the bonuses reduce teacher attrition by 18 to 28 percent. However, we find no evidence the program increases the probability that education majors become secondary math or science teachers upon graduation or alters specific major choices within the education field.

\footnotetext{
*The contents of this report were developed using data provided by Georgia's Academic and Workforce Analysis and Research Data System (GA•AWARDS). However, those contents do not necessarily represent the policy of GA•AWARDS or any of its participating organizations, and you should not assume endorsement by GA•AWARDS or any of its participating organizations. This research was funded in part by the National Center for the Analysis of Longitudinal Data in Education Research (CALDER), which is funded by a consortium of foundations. For more information about CALDER funders, see www.caldercenter.org/about-calder. All opinions expressed in this paper are those of the authors and do not necessarily reflect the views of the CALDER funders.
} 


\section{Introduction}

Traditionally, teachers have been paid according to fixed salary schedules, with wages determined solely by years of experience and educational attainment. Given variation in the opportunity cost of teachers and in the non-pecuniary characteristics of jobs, the fixed salary schedules have led to chronic shortages of teachers in particular subject areas, such as math, science and special education. Ingersoll and Perda (2009) find that roughly 3 to 4 times as many secondary schools report significant difficulty in filling positions in mathematics, special education and science relative to English or social studies. Similarly, Billingsley, Fall, and Williams (2006) report that high percentages of uncertified new special educators enter teaching each year.

Subject-specific teacher shortages which lead to placing out-of-field teachers in classrooms can have negative effects on students in both the short and long-run. While existing research does not find a strong link between teacher credentials and student achievement in general, there is both direct and indirect evidence that having math, science or special education courses taught by teachers with neither a relevant college major nor certification in math and science can have negative consequences for student achievement. The relative effectiveness in math and science of Teach-for-America (TFA) teachers, who have little formal training in education, but typically have strong academic backgrounds and subject area knowledge, suggests that content knowledge is particularly important in these fields. Boyd, et al. (2006) and Kane, Rockoff and Staiger (2006) find TFA teachers are more effective than traditionally prepared teachers in math initially, particularly at the middle school level, in New York City. Xu, Hannaway and Taylor (2011) analyze effectiveness of TFA teachers in North Carolina high schools and find TFA teachers are 
more effective on average over all subjects, with the biggest difference in science and math. The evidence is more direct in the case of special education, where Feng and Sass (2013) find that students with disabilities whose teacher is certified in special education have greater achievement in both math and reading than similar students whose teacher is not special-education certified. Over the longer term, Sass (2015) shows that students whose high school math and physics teachers have degrees in the relevant subject (rather than in education) are more likely to take STEM courses as college freshmen.

To combat subject-specific teacher shortages, a number of non-salary incentives have been employed, including scholarship programs for prospective teachers, housing subsidies, tuition subsidies for existing teachers changing fields and student loan forgiveness (Martin, 2007). We focus here on differential pay by subject -- monetary compensation that is based on the subject area a teacher is trained and teaches in. Most such salary differentials are operated at the district level (Martin, 2007). We are aware of only two statewide programs with differentiated teacher pay by subject area: a bonus program in North Carolina that operated from 2001/02 to 2003/04 and a salary supplement for early-career teachers that has been in effect in Georgia since 2010/11.

In this paper we study the effects of Georgia's statewide salary differential program. We are interested in the impact of differential pay on retention of existing teachers in the short run as well as on the supply of new teachers in the long run. The next section provides a review of prior research on subject-based compensation differentials and section 3 contains background information on Georgia's differential pay system and discusses the data we employ. Empirical methods and results are described in sections 4 and 5, respectively. The last section summarizes our findings and their implications for policy. 


\section{Literature Review}

Prior research on subject-based incentive schemes is quite limited. ${ }^{1}$ Only two previous studies analyze incentive programs targeting specific sub-disciplines for teachers. Clotfelter, Glennie, Ladd, and Vigdor (2008) examine the impacts of a statewide bonus scheme that existed in North Carolina from 2001/02 to 2003/04. To qualify for the program teachers had to be certified as a secondary teacher in math, science, or special education and be working in a high-poverty or low-performing public school. Program participants could earn up to $\$ 1800$ in annual bonuses. Exploiting the multiple eligibility criteria, they implement a triple difference analysis and find the bonus program lowered turnover rates for the targeted teachers by 17 percent.

Feng and Sass (2017) study Florida’s Critical Teacher Shortage Program, which was in effect from 1986/87 through 2009/10. The program provided loan forgiveness for teachers who were certified and taught in "high-need" subjects and (for a brief time) retention bonuses. Employing a difference-in-difference estimator they find the loan forgiveness program decreased attrition of teachers in shortage areas, though the effects varied by subject. Allowing for variation in the size of payments, they find that the effects were more pronounced when loan forgiveness payments were more generous. A triple-difference estimate indicates the bonus program also substantially reduced the likelihood of teachers leaving the public-school sector. Feng and Sass (2017) also present evidence that loan forgiveness recipients were of higher quality (as measured

\footnotetext{
${ }^{1}$ There is also some existing research on incentives to teach in high need schools. Steel, Murnane and Willett (2009) study a California program that offered a $\$ 20,000$ bonus to a select group of new teachers that agreed to teach in highneed schools. Glazerman, et al. (2013) conduct an experimental analysis of the "Teacher Transfer Initiative," a federally funded initiative to that offered $\$ 20,000$ in incentives for high-quality teachers to teach in low-achieving schools for two years. Falch $(2010,2011)$ studies a decade-long bonus program for Norwegian teachers. The program paid wage premiums to teachers in schools with chronic staffing shortages.
} 
by value added) than non-recipients who taught in the same subject, but which were not certified and thus ineligible.

\section{Background and Data}

Driven by concerns over shortages of qualified math and science teachers and a lack of new teachers entering those fields, the 2009 Georgia legislature passed House Bill 280 (HB 280), which produced a de facto differential pay scale for early-career middle and high school math and science teachers. ${ }^{2}$ The legislation increased the pay of new math and science teachers to make it equal to that of a teacher with six years of experience:

"(1) On and after July 1, 2010, and until such date as may be determined by the State Board of Education that mathematics, science, or both are no longer areas in which there an insufficient supply of teachers, a secondary school teacher in a local school system who is or becomes certified in mathematics or science by the Professional Standards Commission shall be moved to the salary step on the state salary schedule that is applicable to six years of creditable service, unless he or she is already on or above such salary step. From such salary step, the teacher shall be attributed one additional year of creditable service on the salary schedule each year for five years.

(2) After five years, such teacher may continue to be attributed one additional year of creditable service on the salary schedule each year if he or she meets or exceeds student achievement criteria established by the Office of Student Achievement.

(3) Upon expiration of five years, or any year thereafter that the teacher does not meet or exceed student achievement criteria as required by paragraph (2) of this subsection, such teacher shall be moved to the salary step applicable to the actual number of years of creditable service which the teacher has accumulated."

${ }^{2}$ When signing the legislation into law, Governor Sonny Perdue noted that "Last year, Georgia produced only one physics teacher. This legislation will help us address the shortage of math and science teachers in the state." (Badertscher, 2011). 
The legislation also provided an annual stipend of $\$ 1,000$ for kindergarten and elementary school teachers who possess an endorsement in mathematics or science. The K-5 incentive is not conditional on experience. Like the salary step increase for secondary math and science teachers, after five years, receipt of the K-5 stipend is conditional on student achievement criteria to be established by the Governor's Office of Student Achievement.

Both the grade 6-12 step increases and K-5 endorsement stipends were "subject to appropriations of the General Assembly." This led the program to be implemented in such a way that 6-12 salary-step increases became an experience-based bonus scheme that is not conditional on future employment. Eligibility for the program is determined by certification status and subject areas taught in October of each year. To be eligible for the grades 6-12 salary incentive, teachers must be certified in math or science, teach math or science in grades 6-12, and have between 0-5 years of experience. A teacher does not qualify for the salary incentives if he or she is teaching math or science under a temporary ("non-renewable") certificate. ${ }^{3}$

A list of eligible teachers is compiled by the end of the calendar year and forwarded to the legislature for funding. Funds are appropriated by the legislature during their regular legislative session in spring of the calendar year following the October employment report. Funds are typically received by the Georgia Department of Education $(\mathrm{GaDOE})$ in July and then dispersed to individual school districts. Teachers receive checks in late August or early September, almost a year after their eligibility is determined. If an individual is no longer teaching in Georgia public schools they still receive the stipend.

\footnotetext{
${ }^{3}$ Eligibility details are specified in Georgia Department of Education (2011) and Georgia Department of Education (2015a).
} 
The amount of the stipend is determined by the difference between the step on the state salary schedule based on a teacher's actual experience and the salary step for a teacher with six years of service. Even though some districts pay teachers more than what is stipulated in the state salary schedule, the amount of the bonus is determined by the applicable salary differences on the state salary schedule, not a teacher's actual salary.

Funds have never been allocated to implement the provision of the statute which extends salary incentives beyond five years of experience. Therefore, the bonus ends when a teacher has reached six years of experience. Since the current implementation of HB 280 does not extend bonuses beyond five years, the provisions that make future bonuses contingent on performance have never been implemented. An example of the bonuses a new secondary math or science teacher with a bachelor's would receive is provided in Table 1. The bonuses total slightly more than $\$ 21,000$ over six years.

The total number of teachers who received the bonuses, broken down by year and type of supplement, is presented in Table 2A. The number of first-time recipients, also broken down by year and supplement type, is presented in Table 2B. Due to the greater number of middle and high school math and science teachers (relative to elementary school teachers with a math or science endorsement) and the more generous supplement to middle and high school math and science teachers, the size of the grades 6-12 program is much larger. After the initial year, about 1,100 to 1,200 middle and high school teachers receive the salary supplement for the first time each year. In contrast, the first-time K-5 supplement recipients have ranged from 85 to just over 200 teachers each year. We therefore focus our analysis on the salary supplements for middle and high school math and science teachers. 
In order to estimate the effects of HB 280 on the supply of math and science teachers, we employ data from Georgia's new statewide longitudinal database, Georgia's Academic and Workforce Analysis and Research Data System (GA•AWARDS). GA•AWARDS combines data from all educational agencies in Georgia as well as unemployment insurance (UI) records from the Georgia Department of Labor. Thus, individual students can be tracked from pre-K through post-secondary institutions and into the labor force. The database includes data from the 2006/07 school year forward and we have received data through the 2014/15 school year. Teachers can be linked to their college records and to the students they teach, though teacher-student linkages are only available for Race-to-the-Top participating districts in 2013/14 and 2014/15. Although student-teacher linkages are limited, we can link students and teachers to schools for all years. We therefore use school-level averages of student characteristics to control for working conditions that may influence teacher labor market decisions.

The GA•AWARDS data include information on employee job codes, teacher certification and years of experience, which can be used to determine whether a teacher meets the requirements to qualify for a salary supplement. In addition, we received data from the GaDOE that indicate which teachers were designated to receive the supplement each year. The list of teachers who qualify (based on job, certification and experience information) does not always correspond to the list of recipients, however. ${ }^{4}$ We therefore rely on the list of actual recipients to identify "treated" teachers.

\footnotetext{
${ }^{4}$ There are a number of interesting anomalies in the program's implementation. Teacher experience is based on Certified/Classified Personnel Information (CPI) data from the GaDOE. The CPI data track "credible" years of service, not actual years of service. For example, a teacher may not have received a step increase because of poor performance or insufficient funding and thus have fewer reported years of service than their actual years of classroom
} 


\section{Econometric Methods}

Below we describe our empirical strategy for estimating the effects of Georgia's differential pay system (HB 280) on the retention of existing teachers and the supply of new teachers.

\section{A. Short-Run Effects: Retention of Existing Teachers}

To estimate the effect of differentiated pay on teacher retention we exploit the fact that teachers had to be both eligible for the differential pay program and the program had to be in place to receive payment. The program had three eligibility criteria: an individual had to be teaching secondary math or science, they had to be certified in the subject they were teaching, and they had to have less than six years of credible service. We initially estimate a simple difference-indifference model of the duration of teaching in Georgia public schools. Specifically, we estimate a Cox proportional hazard model of the form:

$\operatorname{logit}\left[\lambda\left(t_{i}\right)\right]=\beta_{0}+\beta_{1} E_{i}^{M S}+\beta_{2} Z_{t}+\beta_{3}\left(E_{i}^{M S} \times Z_{t}\right)+\beta_{4} X_{i t}$

where $\lambda\left(\mathrm{t}_{\mathrm{i}}\right)$ is the probability that a teaching spell ends at the close of period $\mathrm{t}$ for teacher $\mathrm{i}$, conditional on that spell lasting through period t. ${ }^{5} E_{i}^{M S}$ is an indicator for teachers who ever meet the HB 280 eligibility criteria of being certified and teaching in either secondary math or science and having less than six years of experience. $Z_{t}$ is an indicator that signifies the salary differential program was in place in year t. $\mathrm{X}_{\mathrm{it}}$ is a vector of teacher and school characteristics that typically impact teacher attrition decisions (e.g. demographic characteristics of students at the school,

experience. There is also evidence that some districts may have miscoded science teachers as teaching social science. See Griffin and McGuire (2015) and Georgia Department of Education (2015b).

${ }^{5}$ We determine the end of a spell based on whether a teacher is teaching in a Georgia public school in period $\mathrm{t}+1$. 
teacher race and gender, etc.). The set of coefficients $\beta_{1}$ represent the difference in the hazard rates between ever-eligible teachers (those with less than six years of experience who are certified and teaching secondary math or science) and never-eligible teachers. $\beta_{2}$ represents the impact of being in the period in the differential pay program was in place (school years 2010/11 and later). The coefficient of interest is $\beta_{3}$, which represents the effect of being eligible for the differential pay program and being in a year in which the program was in effect. ${ }^{6} \beta_{3}$ therefore provides the simple difference-in-difference estimate of the impact of the differential-pay program on the exit hazard.

We can also break down the eligibility criteria into its separate components: certified and teaching middle/high school math or science and less than six years of experience. This allows us to estimate a "triple difference" model of teacher attrition:

$$
\begin{aligned}
\operatorname{logit}\left[\lambda\left(t_{i}\right)\right]= & \beta_{0}+\beta_{1} C_{i}^{M S}+\beta_{2} Y_{i t}^{l t 6}+\beta_{3} Z_{t}+\beta_{4}\left(C_{i}^{M S} \times Y_{i t}^{l t 6}\right)+\beta_{5}\left(C_{i}^{M S} \times Z_{t}\right)+ \\
& \beta_{6}\left(Y_{i t}^{l t 6} \times Z_{t}\right)+\beta_{7}\left(C_{i}^{M S} \times Y_{i t}^{l t 6} \times Z_{t}\right)+\beta_{8}\left(X_{i t}\right)
\end{aligned}
$$

where $C_{i t}^{M S}$ indicates teachers who were certified and teaching in math or certified and teaching in science, $Y_{i t}^{\text {lt6 }}$ indicates teachers who have not reached their sixth year of service and $Z_{t}$ indicates the years the program was in effect. The three two-way interaction terms in equation (5) represent: (i) the differential impact of being certified and teaching secondary math and science and having five or fewer years of service $\left(C_{i}^{M S} \times Y_{i t}^{l t 6}\right)$, (ii) the impact of being certified and teaching secondary math or science in a year when the differential pay program was in effect $\left(C_{i}^{M S} \times Z_{t}\right)$, and (iii) the impact of being a teacher with less than six years of experience in the period the differential pay program existed $\left(Y_{i t}^{l t 6} \times Z_{t}\right)$. Lastly, the three-way interaction term,

\footnotetext{
${ }^{6}$ Note, as described above, we use an indicator for actual recipients in place of the interaction term.
} 
$\left(C_{i}^{M S} \times Y_{i t}^{l t 6} \times Z_{t}\right)$, represents the differential hazard rate of teachers who were certified and teaching secondary math or certified and teaching secondary science and possessed less than six years of experience during years in which the differential pay program existed. The coefficient $\beta_{7}$ is thus the difference-in-difference-in-difference estimate of the differential pay program's impact on the exit hazard.

\section{B. Long-Run Effects: The Supply of New Secondary Math and Science Teachers}

There are two ways to become a public-school teacher in Georgia. The most common method is for potential teachers to complete a state-approved certification program, meet content assessment requirements, and then obtain a renewable professional teaching certificate. Alternatively, candidates with a bachelor's degree in any field can obtain a three-year nonrenewable teaching certificate and begin teaching. In order to transition to a renewable teaching certificate, individuals must either complete a traditional university based preparation program or an alternate state approved educator preparation program.

As illustrated in Table 3, a bit more than one-third of middle and high school math and science teachers in Georgia earned their first baccalaureate degree in a field other than education, while just under two-thirds were education majors. While most new public-school teachers in Georgia obtained baccalaureate degrees in education, not all education majors end up as public school teachers. Indeed, about one-third of education majors in Georgia do not become public school teachers within a year of graduation. Thus, one way that pay differentials could impact the supply of new math and science teachers is to boost the likelihood that individuals with bachelor's degrees in education become public-school teachers. 
The likelihood of becoming a public-school teacher will depend on both supply and demand factors for recent college graduates. As a proxy for general labor market conditions we control for the unemployment rate. Higher unemployment rates indicate a depressed demand for workers generally and should be negatively correlated with employment probabilities of new graduates. As a crude measure of worker quality, we include the college GPA of education majors as an additional control.

To assess the effect of HB 280 on the supply of new teachers we estimate the following probit "difference-in-differences" model on the sample of all baccalaureate degree recipients with a major in education:

$\operatorname{Prob}\left[T_{i}^{A n y}=1\right]=\Phi\left[\gamma_{0}+\gamma_{1} D_{i}^{j}+\gamma_{2} Z_{t}+\gamma_{3}\left(D_{i}^{j} \times Z_{t}\right)+\gamma_{4} U_{t}+\gamma_{5} G_{i}\right]$

where $\operatorname{Prob}\left[T_{i}^{A n y}\right]$ is the probability that individual i becomes a public-school teacher in any subject area within one year of receiving a bachelor's degree in education. $D_{i}^{j}$ is an indicator for an education major in subject(s) $\mathrm{j}$, where $\mathrm{j}$ represents the set of majors that are most common for secondary math and science teachers (see Table 3 above) and thus most likely to be able to take advantage of the HB 280 program. $Z_{t}$ is an indicator that signifies the salary differential program was in place in year $t$. $U_{t}$ is the unemployment rate in year $t$ and $G_{i}$ is the college grade point average of individual $i$. The coefficient $\gamma_{1}$ represents the increase in probability of becoming a public-school teacher if an individual majors in education subject(s) $\mathrm{j}$, rather than in some other sub-discipline of education. The second difference is between the pre- and post-HB 280 periods (i.e. before and after 2010), $\gamma_{2}$. The coefficient of interest is $\gamma_{3}$, which represents the effect of graduating with an education major in subject(s) $\mathrm{j}$ in a year in which the differential pay program 
was in effect. The coefficient $\gamma_{3}$ provides the simple difference-in-difference estimate of the impact of the differential-pay program on the likelihood of becoming a teacher, i.e. the difference between graduates with majors(s) $\mathrm{j}$ and other education majors in the probability change from the pre-program program period to the program period.

We also conduct a similar analysis, focusing on becoming a secondary math or science teacher within one year of graduation, $\operatorname{Prob}\left[T_{i}^{M S}\right]$ :

$\operatorname{Prob}\left[T_{i}^{M S}=1\right]=\Phi\left[\gamma_{0}+\gamma_{1} D_{i}^{j}+\gamma_{2} Z_{t}+\gamma_{3}\left(D_{i}^{j} \times Z_{t}\right)+\gamma_{4} U_{t}+\gamma_{5} G_{i}\right]$

While (6) directly estimates the event of interest, becoming a secondary math or science teacher, it does not account for teachers who may not teach a middle or high school math or science course in their first year, but teach those courses later. Thus we view estimates of the parameters in (6) and (7) as complementary. Equation (6) captures graduates who become teachers, some of which may never teach middle or high school math and science while equation (7) focuses on teachers who immediately teach middle and high school math and science courses but omits teachers who may teach in those subject areas in their second or later years of teaching.

In addition to altering the job choice of recent graduates with education degrees, the enhanced pay for early-career math and science teachers engendered by HB 280 could influence college major choice as well. While it is doubtful that the targeted pay increase would cause students interested in significantly different careers to switch to education, those already interested in teaching might be induced to change their specific major within education to be able to qualify for jobs that would be eligible for supplemental pay under HB 280. To estimate this potential longer-run supply effect, we estimate the following model: 
$\operatorname{Prob}\left[D_{i}^{j}=1\right]=\Phi\left[\delta_{0}+\delta_{1} F Z_{i}+\delta_{2} F D_{t}^{E d}+\gamma_{3} U_{t}+\gamma_{4} G_{i}\right]$

where $\operatorname{Prob}\left[D_{i}^{j}=1\right]$ is the probability that individual I earns a degree in education field(s) $\mathrm{j}$ (conditional on having declared an education major by their sophomore year and earning a degree in education), $\mathrm{FZ}$ is our measure of exposure to treatment; it is the fraction of time between a student's sophomore year and the year they graduate that the HB 280 program was in place. $F D_{t}^{E d}$ is the number of BA/BS degrees awarded in the student's graduation year as a fraction of all BA.BS degrees awarded in that year; it is intended to capture the prevailing popularity of education majors in general. As in prior equations, demand is captured by the unemployment rate in year $t$, and the college grade point average of individual $\mathrm{i}, \mathrm{G}_{\mathrm{i}}$.

\section{Empirical Results}

\section{A. Descriptive Analyses}

In Figure 1 we provide a graphical comparison between attrition of early-career teachers in general and early-career secondary math and science teachers. Annual attrition rates for both groups fall in the 10-13 percent range. Consistent with higher opportunity costs, attrition rates are higher for secondary math and science teachers in all but one year.

Figure 2 provides a comparison of attrition between middle and high school math and science teachers who received salary supplements as a result of HB 280 and those which never received a supplement, using a survival analysis framework. Teachers could be in the latter group for four reasons. First, some of these teachers entered teaching and left the Georgia public schools prior to the implementation of HB 280 in 2010/11 and thus never received a bonus. Second, some may have begun their careers as secondary math and science teachers but switched to other grades 
or subjects before the implementation of HB 280. Third, some math and science teachers may never have obtained non-temporary certification during the period of analysis. Forth, there are some teachers who met the criteria for eligibility, but due to implementation issues, may have been left off the list of teachers who were to receive a bonus. In order to compare time until departure from Georgia public schools, only teachers observed during their first year of teaching are included in the sample.

The survival plots indicate that bonus recipients tended to have lower attrition than teachers who did not receive bonuses, particularly in the early years of their career, when supplements were the greatest. After five years of experience (when teachers could no longer receive the supplements) the two groups exhibit similar survival patterns. One potential problem with comparing ever and never-recipients is that non-receipt is partly a function of when a teacher entering the Georgia public school system. Given the sample starts in 2006/07 and program implementation began in 2010/11, teaching spells greater than five years are only observed for teachers who had prior experience when the program began. In order to disentangle these cohort effects, we also present survival estimates for the subset of teachers who began teaching in 2010/11 or later. The results, provided in Figure 3, are similar to those for the full sample.

\section{B. Quantitative Analyses - Teacher Retention}

As noted above, the data available to us begins in $2006 / 07$, just four years prior to the start of the HB 280 program. Thus, we do not observe the first year of teaching for many teachers, but we do know how many years they had taught prior to the start of our analysis period and can conduct a survival analysis over the years they are observed. Put differently, the teaching history of some of the teachers in our sample are "left censored." As shown in Table 4, nearly 60 percent 
of teachers who taught middle/high school math or science during the sample period fall into this left-censored category. Descriptive statistics for both the full sample of middle and high school math and science teachers as was as the subsample of teachers observed for their entire career are presented in Table 4. For the subsample of 8,914 teachers observed in their first year of teaching, roughly half ever received a salary supplement as a result of HB $280 .^{7}$

Estimates from the difference-in-difference hazard models of exit from Georgia public schools are reported in Table 5. For the full sample that includes all teachers, the hazard ratio on the indicator for receipt of a supplement is 0.820 , indicating that receiving differential pay reduced the probability of exit by 18 percent. The estimate is significantly different from zero at better than a 99 percent confidence level. Limiting the sample to teachers who ever taught math or science within the analysis period of 2006/07-2015/16, the results are nearly identical. If we further limit the sample to ever-math-or-science teachers who are observed from their first year forward, the estimated effect of the supplemental pay program on the probability of exit is slightly higher greater; exit rates are reduced by 19 percent.

Estimates from the triple-difference model are presented in Table 6. The estimated impacts of the HB 280 differential pay program on the likelihood of exit are even stronger in this specification. Depending on the sample, the program is estimated to reduce the likelihood of exit from 25 to 28 percent.

\footnotetext{
${ }^{7}$ One potential source of misclassification among these teachers are anomalies in reported teacher experience. As a check, we also estimate models for the subsample of teachers who are observed as rookies and whose reported experience increases by one for every year they taught. Results are similar to those from the full sample.
} 
One potential problem with the difference-in-difference and triple-difference estimators is potential violation of the "parallel trends" assumption. Under the difference-in-difference approach, the ever-treated and never-treated groups are allowed to have different exit rates prior to treatment, but it is assumed that the difference in the rates is constant over time. Thus any change in the difference in the exit rates of the ever-treated and never-treated groups once treatment occurs is attributed to the treatment.

A common approach to testing the parallel-trends assumption is to allow the "effect" of being in the treatment group to vary by year for both the pre- and post-treatment periods. In our context this is accomplished by including indicators for each year (except the base year) and then interacting each of the year indicators with either actual pay supplement receipt (in the posttreatment period) or meeting the requirements to qualify supplemental pay (in the pre-treatment period). If the parallel-trends assumption holds, the coefficients on the (qualified $\times$ year) interactions should be insignificant for the pre-treatment years. The (received bonus $\times$ year) interactions during the post-treatment period allow for the impact of the program to change over time (e.g. if there is initial uncertainty in likelihood of continuation, effects might be stronger in later years).

Table 7 provides estimates of the difference-in-difference and triple-difference models that allow for differential trends in both the pre- and post-treatment periods. The interaction between "qualified" and the two pre-treatment years is not significant in either the DD or DDD specification (the 2008 base year interaction is omitted to avoid collinearity with the overall constant). Thus we fail to reject the parallel-trends assumption. The actual-treatment/year interactions are somewhat variable, though there does appear to be a general upward trend over time. The apparent increasing 
impact of the pay supplement over time is consistent with the program becoming better known and the confidence in its permanency increasing. ${ }^{8}$

\section{Quantitative Analyses - Teacher Supply}

In Table 8 we present estimates of the model that predicts the probability of becoming a public-school teacher, conditional on having earned a bachelor's degree in education. The first column focuses on the interaction between HB 280 and the most common major for middle and high school math and science teachers, Middle/Secondary Education. The second column presents estimates based on the three most common education majors of future middle and high school math and science teachers: Middle/Secondary Education, Special Education, and Math Education or Science Education (incl. specific science education disciplines). When the potentially impacted group is limited to middle/secondary education majors, having the HB 280 supplemental pay program in effect is not found to boost the likelihood of becoming a public-school teacher. However, when the list of potentially effected education majors is expanded to include Special Education and Math or Science Education, the availability of the HB 280 program is associated with an increase in the likelihood of becoming a public-school teacher by 15 percentage points. This effect seems to be mainly driven by the inclusion of special education majors and thus must be interpreted with caution as the demand for special education teachers was increasing over the period in which HB 280 was instituted.

Table 9 presents estimates of equation (7), which also predicts the probability of becoming a public-school teacher, but a positive outcome is limited to middle and high school math and

\footnotetext{
${ }^{8}$ A potential countervailing factor is the average payout is changing over time as the experience distribution of qualifiers is changing.
} 
science teachers. In this case, we find no evidence that the HB 280 program increased the likelihood that graduates with an education degree would become secondary math or science teachers in public schools within one year of earning their college degree.

Finally, estimates of the impact of supplemental pay for math and science teachers on the choice of specific majors within education are presented in Table 10. Conditional on declaring an education major by their sophomore year, we cannot reject the null hypothesis that the supplemental pay program created by HB 280 had no impact of the specific major choice of eventual education baccalaureate degree recipients.

\section{Discussion}

There is growing concern over shortages of teachers, though there is considerable variability in hiring and retaining teachers across disciplines. Finding and keeping teachers in secondary math and science and in special education is much more problematic than recruiting and retaining teachers in other subjects or grade levels. The cause of the shortages seems clear; the opportunity cost of teachers depends on the alternative wage they could earn in occupations outside of public school teaching and thus the equilibrium wage varies across subject areas. Teachers with expertise in math and science are likely to garner relatively higher wages outside of teaching and thus a uniform pay scale is destined to produce shortages of teachers in those subject areas. An obvious solution would be to raise the wages of math, science and special education teachers relative to the wages of other teachers. Little is currently known, however, about the impact differential pay would have on the supply of new teachers and the attrition of existing teachers. 
In this paper we analyze the impact of the only statewide differential pay program currently in existence - Georgia's HB280 supplemental pay for math and science teachers - on both teacher retention and the supply of new teachers. Our findings indicate that Georgia's differential pay system has led to a substantial reduction in attrition rates for secondary math and science teachers. In contrast, we find mixed evidence the program has boosted the likelihood of education graduates will become public school teachers immediately after earning their baccalaureate degrees and no evidence the program increased the probability that education majors would immediately become secondary math or science teachers upon graduation. We also found no evidence of the differential pay program altering specific major choices within the education field.

While it is possible that stronger effects on the supply of new teachers could emerge as the program becomes better known to prospective teachers and confidence in the program's permanence increases, the retention effects alone suggest that differential pay is a viable tool for combating chronic shortages of teachers in "high need" fields like middle and high school math and science. 


\section{References}

Badertscher, Nancy (2011). “Better Pay for Ga. Math, Science Teachers?” The Atlanta JournalConstitution. Retrieved from http://www.ajc.com/news/better-pay-for-ga-987592.html

Billingsley, Bonnie, Anna-Maria Fall, and Thomas Williams (2006). "Who Is Teaching Students With Emotional Disorders? A Profile and Comparison to Other Special Educators," Behavioral Disorders 31(1): 252-264.

Boyd, Donald, Pamela Grossman, Hamilton Lankford, Susanna Loeb, and James Wyckoff (2006). "How Changes in Entry Requirement Alter the Teacher Workforce and Affect Student Achievement," Education Finance and Policy, 1(2): 176-216

Kane, Thomas, Jonah Rockoff, and Douglas Staiger (2008). "What Does Certification Tell Us About Teacher Effectiveness? Evidence from New York City," Economics of Education Review, 27, 615-631.

Clotfelter, Charles, Elizabeth Glennie, Helen Ladd, and Jacob Vigdor (2008). "Would Higher Salaries Keep Teachers in High-Poverty Schools? Evidence from Policy Intervention in North Carolina," Journal of Public Economics 92: 1352-1370

Falch, Torberg (2010). "The Elasticity of Labor Supply at the Establishment Level," Journal of Labor Economics 28(2): 237-66.

Falch, Torberg (2011). "Teacher Mobility Responses to Wage Changes: Evidence from a Quasi-Natural Experiment," American Economic Review: Papers and Proceedings 101(3): 460-465.

Feng, Li and Tim R. Sass (2013). "What Makes Special-Education Teachers Special? Teacher Training and Achievement of Students with Disabilities," Economics of Education Review 36:122-134.

Feng, Li and Tim R. Sass (2017). "The Impact of Incentives to Recruit and Retain Teacher in “Hard-to-Staff” Subjects," Journal of Policy Analysis and Management 37(1): 112-135.

Field, Erica (2009). "Educational Debt Burden and Career Choice: Evidence from a Financial Aid Experiment at NYU Law School," American Economic Journal: Applied Economics 1(1): $1-21$.

Glazerman, Steven, Ali Protik, Bing-ru Teh, Julie Bruch, and Jeffrey Max (2013). Transfer Incentives for High-Performing Teachers: Final Results from a Multisite Randomized Experiment (NCEE 2014-4003). Washington, DC: National Center for Education Evaluation and Regional Assistance, Institute of Education Sciences, U.S. Department of Education.

Georgia Department of Education (2011). “HB280 Business Rules Grades 6-12.” Atlanta, GA. 
Georgia Department of Education (2015a). "HB 280 Guidance: Differentiated Compensation for Math and Science Teachers." Atlanta, GA.

Georgia Department of Education (2015b). "Top Ten List for HB280 Math and Science Teachers Supplement." Atlanta, GA.

Griffin, Greg S. and Leslie McGuire (2015). "Math and Science Salary Incentives for Teachers." Georgia Department of Audits and Accounts, Performance Audit Division, Special Examination Report No. 15-14.

Ingersoll, Richard M., and David Perda (2009). "The Mathematics and Science Teacher Shortage: Fact and Myth," CPRE Research Report \#RR-62.

Martin, Anne (2007). "The Use of Diversified Compensation Systems to Address Equitable Teacher Distribution," Education Commission of the States, Issue Paper No. TQ-07-04.

Pathman, Donald E., Thomas R. Konrad, Tonya S. King, Donald H. Taylor Jr., and Gary G. Koch (2004). "'Outcomes of States' Scholarship, Loan Repayment, and Related Programs for Physicians," Medical Care 42(6): 560-8.

Sass, Tim (2015). “Understanding the STEM Pipeline," unpublished manuscript.

Steele, Jennifer L., Richard J. Murnane, and John B. Willett (2009). "Do Financial Incentives Help Low-Performing Schools Attract and Keep Academically Talented Teachers? Evidence from California," Journal of Policy Analysis and Management 29(3): 451-478.

Xu, Z., Hannaway, J., \& Taylor, C. (2011). "Making a difference? The Effects of Teach for America in High School," Journal of Policy Analysis and Management 30(3), 447-469. 
Figure 1. Percentage of Teachers Leaving Georgia Public Schools by Year (Teachers with 5 or Less Years of Experience)

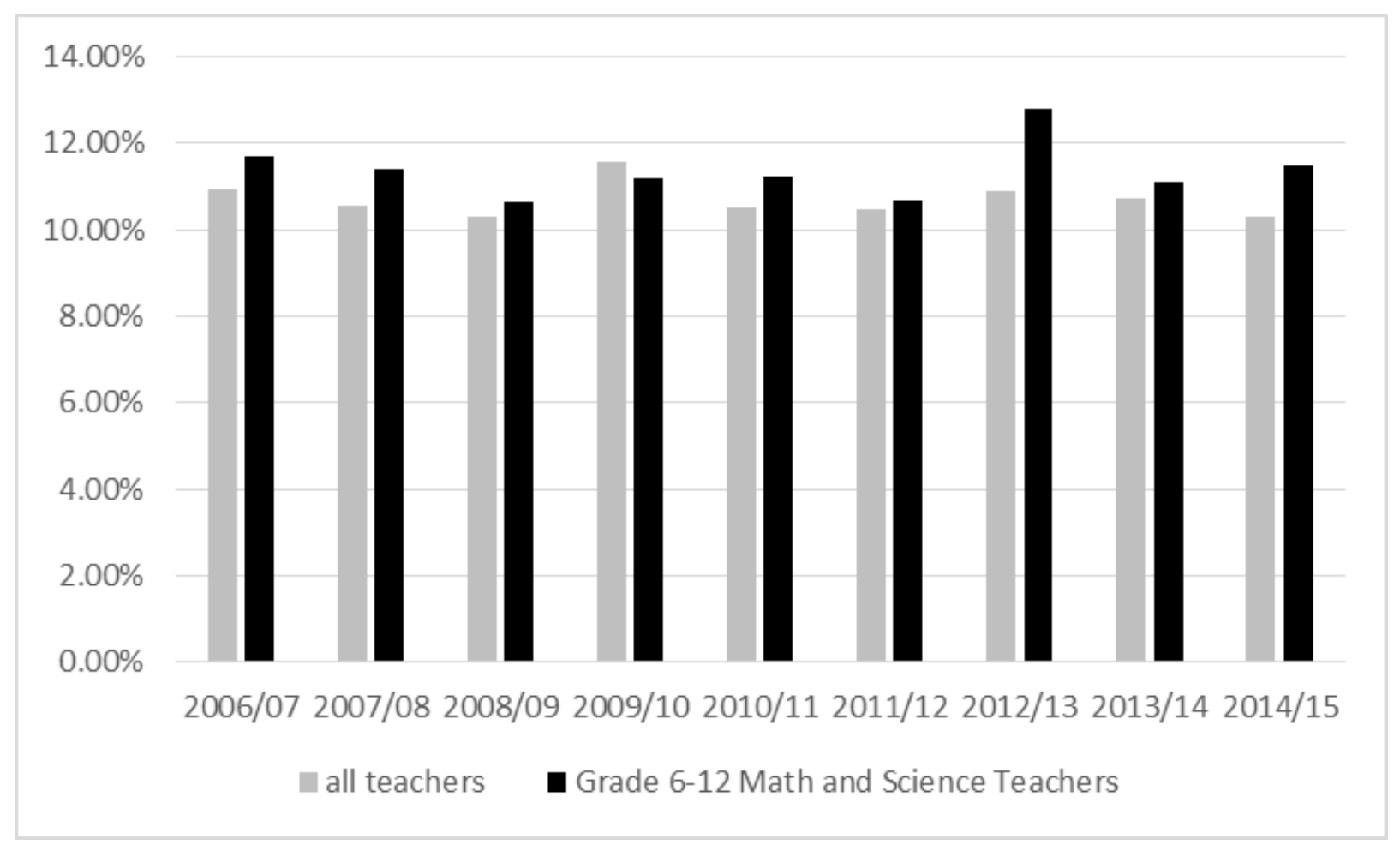


Figure 2. Kaplan-Meier Survival Estimates of Teaching in Georgia Public Schools (Math/Science Teachers Observed in Their First Year of Teaching, 2006/07-2014/15)

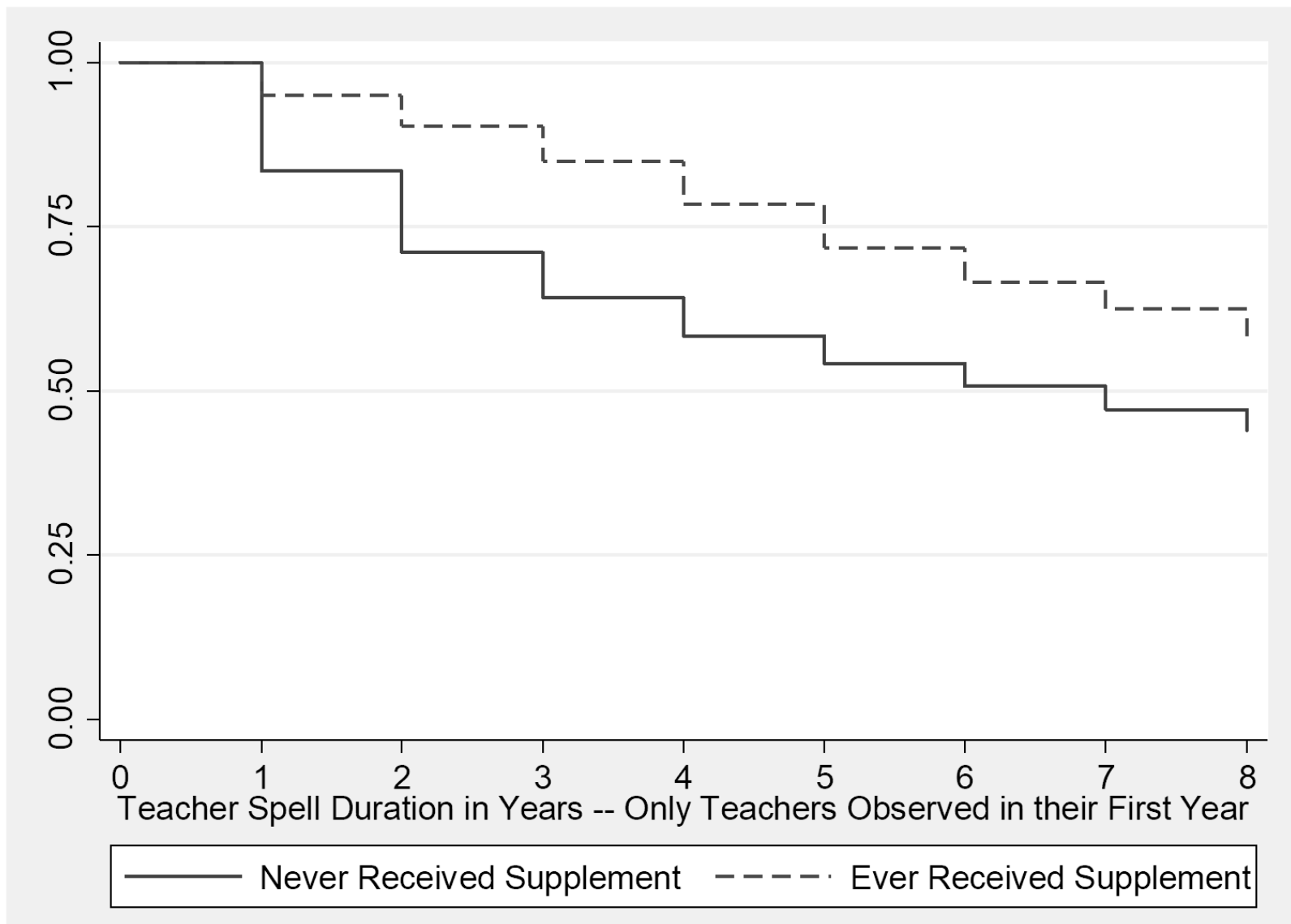


Figure 3. Kaplan-Meier Survival Estimates of Teaching in Georgia Public Schools (Math/Science Teachers Observed in Their First Year of Teaching, 2010/11-2014/15)

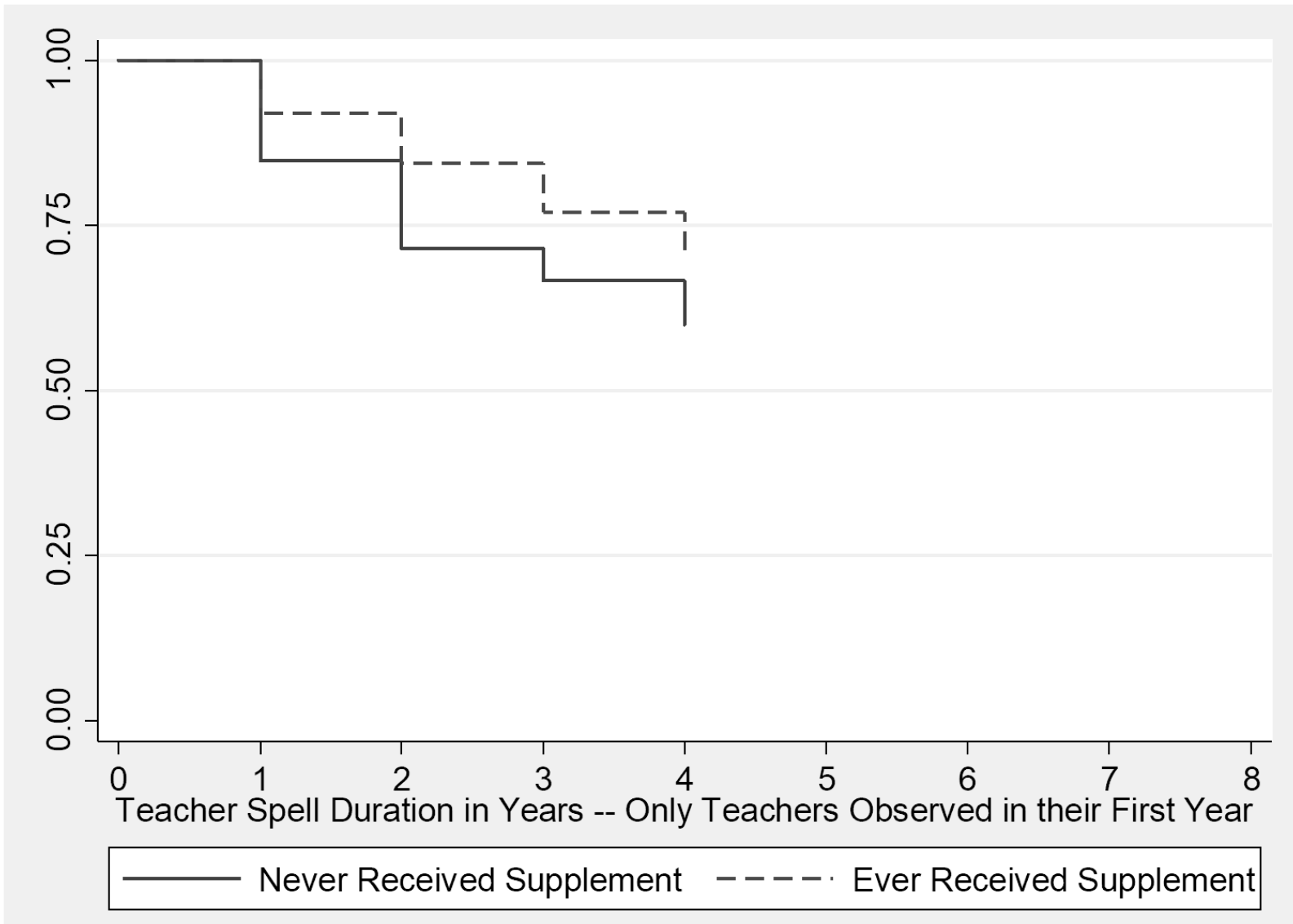


Table 1. Salary Supplement for a 6-12 Math/Science Teacher in Georgia

\begin{tabular}{|l|r|r|r|}
\hline \multirow{2}{*}{$\begin{array}{c}\text { Actual Years of } \\
\text { Experience }\end{array}$} & \multicolumn{3}{|c|}{$\begin{array}{c}\text { Statewide Salary Schedule } \\
\text { (Teacher with a Bachelor's Degree) }\end{array}$} \\
\cline { 2 - 4 } & $\begin{array}{c}\text { Salary Based on } \\
\text { Actual Years of } \\
\text { Experience }\end{array}$ & $\begin{array}{c}\text { Salary Based on } \\
\text { Six Years of } \\
\text { Experience }\end{array}$ & Supplement \\
\hline 0 & $\$ 33,424$ & $\$ 37,985$ & $\$ 4,561$ \\
\hline 1 & $\$ 33,424$ & $\$ 37,985$ & $\$ 4,561$ \\
\hline 3 & $\$ 33,424$ & $\$ 37,985$ & $\$ 4,561$ \\
\hline 4 & $\$ 34,427$ & $\$ 37,985$ & $\$ 3,558$ \\
\hline 5 & $\$ 35,460$ & $\$ 37,985$ & $\$ 2,525$ \\
\hline Total & $\$ 36,524$ & $\$ 37,985$ & $\$ 1,461$ \\
\hline
\end{tabular}


Table 2A. Number of Teachers Receiving Differential Pay by Year

\begin{tabular}{|c|c|c|c|c|c|c|c|}
\hline \multirow[t]{2}{*}{ Year } & \multicolumn{4}{|c|}{ All Teachers } & \multicolumn{3}{|c|}{ 6-12 Math and Science Teachers } \\
\hline & $\begin{array}{l}\text { Did Not } \\
\text { Receive }\end{array}$ & $\begin{array}{l}\text { Received } \\
\text { K-5 Bonus }\end{array}$ & $\begin{array}{l}\text { Received } \\
\text { 6-12 Bonus }\end{array}$ & Total & $\begin{array}{l}\text { Did Not } \\
\text { Receive }\end{array}$ & $\begin{array}{l}\text { Received } \\
\text { 6-12 Bonus }\end{array}$ & Total \\
\hline $2006 / 07$ & 118,434 & 0 & 0 & 118,434 & 19,597 & 0 & 19,597 \\
\hline $2007 / 08$ & 122,274 & 0 & 0 & 122,274 & 19,947 & 0 & 19,947 \\
\hline 2008/09 & 122,474 & 0 & 0 & 122,474 & 20,572 & 0 & 20,572 \\
\hline $2009 / 10$ & 118,392 & 0 & 0 & 118,392 & 20,105 & 0 & 20,105 \\
\hline $2010 / 11$ & 109,784 & 0 & 3,765 & 113,169 & 16,606 & 3,334 & 19,940 \\
\hline $2011 / 12$ & 107,557 & 149 & 3,274 & 110,661 & 16,997 & 3,274 & 20,271 \\
\hline $2012 / 13$ & 105,117 & 208 & 3,107 & 108,432 & 16,893 & 3,105 & 19,998 \\
\hline $2013 / 14$ & 103,425 & 380 & 3,077 & 106,443 & 16,759 & 3,075 & 19,834 \\
\hline $2014 / 15$ & 103,483 & 529 & 3,188 & 107,200 & 16,580 & 3,187 & 19,767 \\
\hline
\end{tabular}


Table 2B. Number of Teachers Receiving Differential Pay for the First Time by Year

\begin{tabular}{|c|c|c|c|c|c|c|c|}
\hline \multirow[t]{2}{*}{ Year } & \multicolumn{4}{|c|}{ All Teachers } & \multicolumn{3}{|c|}{ 6-12 Math and Science Teachers } \\
\hline & $\begin{array}{l}\text { Did Not } \\
\text { Receive }\end{array}$ & $\begin{array}{c}\text { Received } \\
\text { K-5 Bonus }\end{array}$ & $\begin{array}{c}\text { Received } \\
\text { 6-12 Bonus }\end{array}$ & Total & $\begin{array}{l}\text { Did Not } \\
\text { Receive }\end{array}$ & $\begin{array}{l}\text { Received } \\
\text { 6-12 Bonus }\end{array}$ & Total \\
\hline $2006 / 07$ & 118,434 & 0 & 0 & 118,434 & 19,597 & 0 & 19,597 \\
\hline $2007 / 08$ & 122,274 & 0 & 0 & 122,274 & 19,947 & 0 & 19,947 \\
\hline 2008/09 & 122,474 & 0 & 0 & 122,474 & 20,572 & 0 & 20,572 \\
\hline $2009 / 10$ & 118,392 & 0 & 0 & 118,392 & 20,105 & 0 & 20,105 \\
\hline $2010 / 11$ & 109,784 & 0 & 3,765 & 113,549 & 16,606 & 3,334 & 19,940 \\
\hline $2011 / 12$ & 109,540 & 149 & 1,291 & 110,980 & 18,974 & 1,291 & 20,265 \\
\hline $2012 / 13$ & 107,204 & 85 & 1,143 & 108,432 & 18,847 & 1,141 & 19,988 \\
\hline $2013 / 14$ & 105,610 & 189 & 1,083 & 106,882 & 18,745 & 1,082 & 19,827 \\
\hline $2014 / 15$ & 105,830 & 203 & 1,167 & 107,200 & 18,588 & 1,166 & 19,754 \\
\hline
\end{tabular}


Table 3. First BA/BS Degree of Teachers in Georgia who Ever Taught Middle/High Math and Science Courses during 2008-2016 and Earned a BA/BS Degree in Georgia in 20072015

\begin{tabular}{|l|c|}
\hline First BA/BS Degree & $\begin{array}{c}\text { Proportion of Math or } \\
\text { Science Teachers with } \\
\text { Known BA/BS Degree }\end{array}$ \\
\hline Any Non-Education & 0.373 \\
Math/Statistics & 0.086 \\
Biology/Bio Med & 0.074 \\
Physical Sciences (incl. specific disciplines) & 0.028 \\
Engineering & 0.011 \\
Any Education Degree & 0.627 \\
Middle or Secondary Education & 0.264 \\
Special Education & 0.121 \\
Math Education or Science Education (incl. specific disciplines) & 0.088 \\
Early Childhood/Pre-K Education & 0.074 \\
Elementary Education & 0.042 \\
\hline Observations & 6,406 \\
\hline
\end{tabular}


Table 4. Means of Characteristics of 6-12 Math and Science Teachers

\begin{tabular}{|c|c|c|c|c|c|c|}
\hline & \multicolumn{3}{|c|}{$\begin{array}{c}\text { All 6-12 Math and Science } \\
\text { Teachers }\end{array}$} & \multicolumn{3}{|c|}{$\begin{array}{c}\text { 6-12 Math and Science Teachers } \\
\text { Observed in their First Year of } \\
\text { Teaching }\end{array}$} \\
\hline & All & $\begin{array}{l}\text { Teachers } \\
\text { Who } \\
\text { Received } \\
\text { Bonus }\end{array}$ & $\begin{array}{l}\text { Teachers } \\
\text { Who Did } \\
\text { Not } \\
\text { Receive } \\
\text { Bonus }\end{array}$ & All & $\begin{array}{l}\text { Teachers } \\
\text { Who } \\
\text { Received } \\
\text { Bonus }\end{array}$ & $\begin{array}{l}\text { Teachers } \\
\text { Who Did } \\
\text { Not } \\
\text { Receive } \\
\text { Bonus }\end{array}$ \\
\hline & Mean & Mean & Mean & Mean & Mean & Mean \\
\hline Female & 0.7438 & 0.7138 & 0.7458 & 0.7147 & 0.7037 & 0.7249 \\
\hline Black & 0.2480 & 0.2949 & 0.2448 & 0.3014 & 0.2534 & 0.3461 \\
\hline Hispanic & 0.0081 & 0.0169 & 0.0075 & 0.0141 & 0.0135 & 0.0147 \\
\hline Asian/PI & 0.0147 & 0.0200 & 0.0143 & 0.0213 & 0.0199 & 0.0226 \\
\hline Other Non-White & 0.0057 & 0.0082 & 0.0056 & 0.0095 & 0.0086 & 0.0104 \\
\hline Renewable/Prof. Cert. & 0.5661 & 0.5072 & 0.5701 & 0.4022 & 0.4714 & 0.3380 \\
\hline Non-renewable Cert. & 0.0623 & 0.1174 & 0.0586 & 0.1829 & 0.1352 & 0.2272 \\
\hline Other Cert. & 0.3816 & 0.3754 & 0.3820 & 0.4149 & 0.3935 & 0.4348 \\
\hline Ever Taught ELA & 0.1526 & 0.0887 & 0.1569 & 0.1316 & 0.0840 & 0.1758 \\
\hline Ever Taught Math & 0.4822 & 0.5431 & 0.4782 & 0.4933 & 0.5318 & 0.4576 \\
\hline Ever Taught Reading & 0.0689 & 0.0221 & 0.0720 & 0.0686 & 0.0286 & 0.1057 \\
\hline Ever Taught Science K-5 & 0.0397 & 0.0200 & 0.0410 & 0.0503 & 0.0207 & 0.0777 \\
\hline Ever Taught Science 6-12 & 0.3310 & 0.3677 & 0.3285 & 0.3000 & 0.3548 & 0.2491 \\
\hline Ever Taught Social Studies & 0.1210 & 0.0790 & 0.1238 & 0.1169 & 0.0752 & 0.1556 \\
\hline Ever Taught ESOL & 0.0027 & 0.0026 & 0.0027 & 0.0019 & 0.0018 & 0.0020 \\
\hline Ever Taught Gifted & 0.0036 & 0.0010 & 0.0038 & 0.0003 & 0.0005 & 0.0002 \\
\hline Observations & 31,171 & 1,950 & 29,221 & 12,610 & 6,074 & 6,536 \\
\hline
\end{tabular}


Table 5. Hazard Ratios for Difference-in-Differences (DD) Teacher Duration Models

\begin{tabular}{|l|c|c|c|}
\hline & DD - Full Sample & $\begin{array}{c}\text { DD - Math/Sci. } \\
\text { Only }\end{array}$ & $\begin{array}{c}\text { DD - Math/Sci. } \\
\text { Only - Exclude } \\
\text { Left Censored }\end{array}$ \\
\hline Received Supplement in Current & $0.820^{* *}$ & $0.819^{* *}$ & $0.808^{* *}$ \\
Year & $(0.030)$ & $(0.033)$ & $(0.037)$ \\
Ever Qualified & $1.064^{* *}$ & $1.223^{* *}$ & $1.290^{* *}$ \\
Program in Effect & $(0.022)$ & $(0.032)$ & $(0.045)$ \\
Female Teacher & $1.072^{* *}$ & $1.305^{* *}$ & $1.334^{* *}$ \\
Black Teacher & $(0.018)$ & $(0.047)$ & $(0.095)$ \\
Hispanic Teacher & 1.015 & $0.927^{* *}$ & $0.881^{* *}$ \\
Asian/PI Teacher & $(0.012)$ & $(0.020)$ & $(0.032)$ \\
& $0.878^{* *}$ & $0.910^{* *}$ & $0.878^{* *}$ \\
Other Non-White Teacher & $(0.011)$ & $(0.024)$ & $(0.039)$ \\
& 1.019 & 1.034 & 1.105 \\
School-Level Student & $(0.036)$ & $(0.094)$ & $(0.140)$ \\
Demographic Controls & $1.152^{* *}$ & $1.268^{* *}$ & $1.463^{* *}$ \\
Year Controls & $(0.052)$ & $(0.089)$ & $(0.141)$ \\
\hline Observations & $1.122^{* *}$ & 1.131 & 1.034 \\
\hline Log likelihood & $(0.047)$ & $(0.092)$ & $(0.149)$ \\
\hline
\end{tabular}

School-level student demographics include Percent Limited English Proficiency, Percent Foreign Born, Percent Primary Language Non-English, Percent Free/Reduced-Price Lunch, Percent Immigrant, Percent Homeless, Percent Retained in Grade, Average Age Within Grade, Percent Gifted and Percent with Disabilities. Reported estimates are exponentiated coefficients; Standard errors in parentheses. ${ }^{*} p<0.05,{ }^{* *} p<0.01$ 
Table 6. Hazard Ratios for Triple-Difference (DDD) Teacher Duration Models

\begin{tabular}{|c|c|c|c|}
\hline & $\begin{array}{l}\text { DDD - Full } \\
\text { Sample }\end{array}$ & $\begin{array}{l}\text { DDD - Math/Sci. } \\
\text { Only }\end{array}$ & $\begin{array}{c}\text { DDD - Math/Sci. } \\
\text { Only - Exclude } \\
\text { Left Censored }\end{array}$ \\
\hline $\begin{array}{l}\text { Received Supplement in Current } \\
\text { Year }\end{array}$ & $\begin{array}{l}0.747^{* *} \\
(0.030)\end{array}$ & $\begin{array}{l}0.737^{* *} \\
(0.035)\end{array}$ & $\begin{array}{l}0.722^{* *} \\
(0.036)\end{array}$ \\
\hline $\begin{array}{l}\text { Ever Certified and Teaching Math } \\
\text { or Science }\end{array}$ & $\begin{array}{l}0.726^{* *} \\
(0.020)\end{array}$ & $\begin{array}{l}0.788^{* *} \\
(0.032)\end{array}$ & $\begin{array}{l}0.706^{* *} \\
(0.075)\end{array}$ \\
\hline$<6$ Years of Experience & $\begin{array}{l}1.410^{* *} \\
(0.042)\end{array}$ & $\begin{array}{c}1.092 \\
(0.069)\end{array}$ & $\begin{array}{c}0.851 \\
(0.141)\end{array}$ \\
\hline Program in Effect & $\begin{array}{l}1.069^{* *} \\
(0.019)\end{array}$ & $\begin{array}{r}1.098^{*} \\
(0.051)\end{array}$ & $\begin{array}{c}0.797 \\
(0.145)\end{array}$ \\
\hline $\begin{array}{l}\text { Certified and Teaching Math or } \\
\text { Science } \times<6 \text { Years of Experience }\end{array}$ & $\begin{array}{l}1.217^{* *} \\
(0.041)\end{array}$ & $\begin{array}{l}1.290^{* *} \\
(0.058)\end{array}$ & $\begin{array}{l}1.314^{* *} \\
(0.105)\end{array}$ \\
\hline $\begin{array}{l}\text { Certified and Teaching Math or } \\
\text { Science } \times \text { Program in Effect }\end{array}$ & $\begin{array}{l}1.361^{* *} \\
(0.040)\end{array}$ & $\begin{array}{l}1.360^{* *} \\
(0.059)\end{array}$ & $\begin{array}{l}1.551^{* *} \\
(0.135)\end{array}$ \\
\hline $\begin{array}{l}<6 \text { Years of Exp. } \times \text { Program in } \\
\text { Effect }\end{array}$ & $\begin{array}{l}0.889^{* *} \\
(0.021)\end{array}$ & $\begin{array}{c}1.072 \\
(0.055)\end{array}$ & $\begin{array}{c}1.419^{*} \\
(0.252)\end{array}$ \\
\hline Female Teacher & $\begin{array}{c}1.016 \\
(0.012)\end{array}$ & $\begin{array}{l}0.929^{* *} \\
(0.020)\end{array}$ & $\begin{array}{l}0.889^{* *} \\
(0.033)\end{array}$ \\
\hline Black Teacher & $\begin{array}{l}0.876^{* *} \\
(0.011)\end{array}$ & $\begin{array}{l}0.904^{* *} \\
(0.023)\end{array}$ & $\begin{array}{l}0.865^{* *} \\
(0.039)\end{array}$ \\
\hline Hispanic Teacher & $\begin{array}{c}1.014 \\
(0.036)\end{array}$ & $\begin{array}{c}1.033 \\
(0.094)\end{array}$ & $\begin{array}{c}1.099 \\
(0.139)\end{array}$ \\
\hline Asian/PI Teacher & $\begin{array}{l}1.173^{* *} \\
(0.053)\end{array}$ & $\begin{array}{l}1.281^{* *} \\
(0.090)\end{array}$ & $\begin{array}{l}1.486^{* *} \\
(0.144)\end{array}$ \\
\hline Other Non-White Teacher & $\begin{array}{l}1.116^{* *} \\
(0.047)\end{array}$ & $\begin{array}{c}1.120 \\
(0.091)\end{array}$ & $\begin{array}{c}1.019 \\
(0.147)\end{array}$ \\
\hline $\begin{array}{l}\text { School-Level Student } \\
\text { Demographic Controls }\end{array}$ & $\checkmark$ & $\checkmark$ & $\checkmark$ \\
\hline Year Controls & $\checkmark$ & $\checkmark$ & $\sqrt{ }$ \\
\hline $\begin{array}{l}\text { Observations } \\
\text { Log likelihood }\end{array}$ & $\begin{array}{r}639,220 \\
-493,598\end{array}$ & $\begin{array}{l}160,308 \\
-98,757\end{array}$ & $\begin{array}{r}42,660 \\
-31,282\end{array}$ \\
\hline
\end{tabular}

School-level student demographics include Percent Limited English Proficiency, Percent Foreign Born, Percent Primary Language Non-English, Percent Free/Reduced-Price Lunch, Percent Immigrant, Percent Homeless, Percent Retained in Grade, Average Age Within Grade, Percent Gifted and Percent with Disabilities. Reported estimates are exponentiated coefficients; Standard errors in parentheses. ${ }^{*} p<0.05,{ }^{* * *} p<0.01$ 
Table 7: Hazard Ratios for Difference-in-Differences (DD) and Triple-Difference Models with Pre-/Post-Year Interactions

\begin{tabular}{|c|c|c|}
\hline & DD - Full Sample & DDD - Full Sample \\
\hline Received Supplement $\times$ Year 2011 & $\begin{array}{l}0.778^{* *} \\
(0.057)\end{array}$ & $\begin{array}{l}0.720^{* *} \\
(0.055)\end{array}$ \\
\hline Received Supplement $\times$ Year 2012 & $\begin{array}{l}0.730^{* *} \\
(0.059)\end{array}$ & $\begin{array}{l}0.674^{* *} \\
(0.056)\end{array}$ \\
\hline Received Supplement $\times$ Year 2013 & $\begin{array}{l}0.815^{* *} \\
(0.062)\end{array}$ & $\begin{array}{l}0.757^{* *} \\
(0.059)\end{array}$ \\
\hline Received Supplement $\times$ Year 2014 & $\begin{array}{l}0.818^{* *} \\
(0.063)\end{array}$ & $\begin{array}{l}0.767^{* *} \\
(0.061)\end{array}$ \\
\hline Received Supplement $\times$ Year 2015 & $\begin{array}{c}0.959 \\
(0.069)\end{array}$ & $\begin{array}{c}0.902 \\
(0.067)\end{array}$ \\
\hline Qualified $\times$ Year 2009 & $\begin{array}{c}0.948 \\
(0.068)\end{array}$ & $\begin{array}{l}1.076 \\
(0.088)\end{array}$ \\
\hline Qualified $\times$ Year 2010 & $\begin{array}{c}1.020 \\
(0.068)\end{array}$ & $\begin{array}{c}1.157 \\
(0.090)\end{array}$ \\
\hline Ever Qualified & $\begin{array}{l}1.067^{* *} \\
(0.025)\end{array}$ & \\
\hline Ever Certified and Teaching Math or Science & & $\begin{array}{l}0.715^{* *} \\
(0.021)\end{array}$ \\
\hline$<6$ Years of Experience & & $\begin{array}{l}1.403^{* *} \\
(0.042)\end{array}$ \\
\hline $\begin{array}{l}\text { Certified and Teaching Math or Science } \times<6 \\
\text { Years of Experience }\end{array}$ & & $\begin{array}{l}1.173^{* *} \\
(0.047)\end{array}$ \\
\hline $\begin{array}{l}\text { Certified and Teaching Math or Science } \times \\
\text { Program in Effect }\end{array}$ & & $\begin{array}{l}1.390^{* *} \\
(0.045)\end{array}$ \\
\hline$<6$ Years of Experience $\times$ Program in Effect & & $\begin{array}{l}0.897^{* *} \\
(0.021)\end{array}$ \\
\hline Female Teacher & $\begin{array}{c}1.015 \\
(0.012)\end{array}$ & $\begin{array}{c}1.017 \\
(0.012)\end{array}$ \\
\hline Black Teacher & $\begin{array}{c}0.878^{* *} \\
(0.011)\end{array}$ & $\begin{array}{c}0.876^{* *} \\
(0.011)\end{array}$ \\
\hline Hispanic Teacher & $\begin{array}{c}1.019 \\
(0.036)\end{array}$ & $\begin{array}{c}1.014 \\
(0.036)\end{array}$ \\
\hline
\end{tabular}




\begin{tabular}{|l|c|c|} 
Asian/PI Teacher & $1.151^{* *}$ & $1.172^{* *}$ \\
Other Non-White Teacher & $(0.052)$ & $(0.053)$ \\
Year = 2009 & $1.122^{* *}$ & $1.117^{* *}$ \\
& $(0.047)$ & $(0.047)$ \\
Year $=2010$ & $0.911^{* *}$ & $0.912^{* *}$ \\
& $(0.016)$ & $(0.017)$ \\
Year $=2012$ & $1.052^{* *}$ & $1.061^{* *}$ \\
Year $=2013$ & $(0.017)$ & $(0.019)$ \\
Year $=2014$ & $1.059^{* *}$ & $1.061^{* *}$ \\
& $(0.018)$ & $(0.018)$ \\
Year $=2015$ & $1.139^{* *}$ & $1.140^{* *}$ \\
School-Level Student Demographic Controls & $(0.019)$ & $(0.019)$ \\
& $1.146^{* *}$ & $1.149^{* *}$ \\
\hline Observations & $(0.020)$ & $(0.020)$ \\
Log likelihood & $1.124^{* *}$ & $1.126^{* *}$ \\
\hline
\end{tabular}

Exponentiated coefficients; Standard errors in parentheses. ${ }^{*} p<0.05,{ }^{* *} p<0.01$ 
Table 8. Probit Difference-in-Differences Estimates of the Probability of Becoming a Public School Teacher in any Subject Within One Year of Graduation, Conditional on Earning a Bachelor's Degree in Education

\begin{tabular}{|l|c|c|}
\hline & \multicolumn{2}{|c|}{$\begin{array}{c}\text { Become a Public School Teacher Within } \\
\text { One Year of Receiving Bachelor's Degree }\end{array}$} \\
\hline $\begin{array}{l}\text { BA/BS in Middle School or Secondary Education } \\
\times \text { Program in Effect }\end{array}$ & 0.106 & \\
BA/BS in Middle School, Secondary, Math, & $(0.055)$ & $0.150^{* *}$ \\
Science or Special Education $\times$ Program in Effect & & $(0.042)$ \\
& & \\
BA/BS in Middle School or Secondary Education & $0.402^{* *}$ & \\
BA/BS in Middle School, Secondary, Math, & $(0.044)$ & $0.400^{* *}$ \\
Science or Special Education & & $(0.033)$ \\
& & 0.007 \\
Program in Effect & 0.025 & $(0.021)$ \\
College GPA & $(0.019)$ & $0.436^{* *}$ \\
Unemployment Rate (in percent) & $0.447^{* *}$ & $(0.022)$ \\
& $(0.022)$ & $-0.187^{* *}$ \\
Constant & $-0.187^{* *}$ & $(0.005)$ \\
\hline Observations & $(0.005)$ & $-0.328^{* *}$ \\
\hline
\end{tabular}

Reported coefficients are marginal effects. Standard errors in parentheses. ${ }^{*} p<0.05,{ }^{* *} p<0.01$ 
Table 9. Probit Difference-in-Differences Estimates of the Probability of Teaching Middle/High School Math or Science Within One Year of Graduation, Conditional on Earning a Bachelor's Degree in Education

\begin{tabular}{|l|c|c|}
\hline & \multicolumn{2}{|c|}{$\begin{array}{c}\text { Teach Middle or High School Math or } \\
\text { Science in a Public School Within One } \\
\text { Year of Receiving Bachelor's Degree }\end{array}$} \\
\hline $\begin{array}{l}\text { BA/BS in Middle School or Secondary Education } \\
\times \text { Program in Effect }\end{array}$ & -0.059 & \\
BA/BS in Middle School, Secondary, Math, & $(0.062)$ & -0.123 \\
Science or Special Education $\times$ Program in Effect & & $(0.067)$ \\
BA/BS in Middle School or Secondary Education & $1.273^{* *}$ & \\
BA/BS in Middle School, Secondary, Math, & $(0.049)$ & $1.717^{* *}$ \\
Science or Special Education & & $(0.054)$ \\
Program in Effect & & $0.177^{* *}$ \\
College GPA & $0.073^{*}$ & $(0.055)$ \\
Unemployment Rate (in percent) & $(0.034)$ & 0.002 \\
Constant & 0.053 & $(0.037)$ \\
\hline Observations & $(0.034)$ & $-0.057^{* *}$ \\
\hline
\end{tabular}

Reported coefficients are marginal effects. Standard errors in parentheses. ${ }^{*} p<0.05,{ }^{* *} p<0.01$ 
Table 10. Probit Estimates of the Probability of Earning a BA/BS in Specified Education Majors, Conditional on Having Declared an Education Major by Sophomore Year and Earning a BA/BS Degree in any Education Major

\begin{tabular}{|l|c|c|}
\hline & $\begin{array}{c}\text { BA/BS in Middle } \\
\text { School or } \\
\text { Secondary School } \\
\text { Education }\end{array}$ & $\begin{array}{c}\text { BA/BS in Middle } \\
\text { School, Secondary } \\
\text { School, Math, } \\
\text { Science or Special } \\
\text { Education }\end{array}$ \\
\hline Fraction of Time Between Sophomore Year and & -0.029 & -0.004 \\
Graduation Year Program in Effect & $(0.089)$ & $(0.076)$ \\
College GPA & $-0.138^{* *}$ & -0.011 \\
Unemployment Rate (in percent) & $(0.047)$ & $(0.040)$ \\
BA/BS Degrees in Education in Graduation Year & -0.016 & -0.011 \\
as a Fraction of All BA/BS Degrees & $(0.029)$ & $(0.025)$ \\
Constant & -1.008 & -1.194 \\
Observations & $(1.209)$ & $(1.041)$ \\
& 0.293 & 0.395 \\
\hline
\end{tabular}

Reported coefficients are marginal effects. Standard errors in parentheses. ${ }^{*} p<0.05,{ }^{* *} p<0.01$ 